\title{
Bed usage and disease specific mortality within ICD chapters
}

\author{
ROGER WEST
}

From the Norfolk Area Health Authority

SUMMARY Using Hospital In-Patient Enquiry (HIPE) data (Department of Health and Social Security and Office of Population Censuses and Surveys, 1974), the relationship between mortality and bed usage was examined for a number of disease categories within 10 chapters of the International Classification of Diseases (ICD) (World Health Organisation, 1967). There was found to be significant correlation within six chapters for males and within six chapters for females. The use of standardised mortality ratios (SMRs) in the formula of the Resource Allocation Working Party (RAWP) (Department of Health and Social Security, 1976) for certain chapters where no correlation could be demonstrated is questioned. It is suggested that separate SMRs for urinary disease and genital disease should be used and that the SMRs for Chapter XVII (accidents, poisoning, and violence) should either be omitted from the formula or determined separately for subdivisions of the chapter.

Since the publication of the report of the Resource Allocation Working Party (RAWP) (Department of Health and Social Security, 1976), the concept of using standardised mortality ratios (SMRs) as a weighting factor in the formula for determining the allocation of resources for non-psychiatric hospital services has been the subject of a continuing debate. Most of this has centred on the acceptability of using mortality as a proxy measure of morbidity (Barr and Logan, 1977; Forster, 1977). One aspect of the RAWP's proposals which deserves closer scrutiny is the recommendation that for the purposes of applying the formula, SMRs should be calculated for broad groups of conditions in accordance with the chapter headings of the International Classification of Diseases (ICD) (World Health Organisation, 1967). Each chapter encompasses a wide range of diseases, not all of which make heavy demands upon hospital resources, and not all of which are important causes of mortality. This study sets out to examine how closely the mortality in individual disease categories in each chapter heading correlates to the demand made by those categories upon hospital beds.

Method

Reference was made to table 9 of the Hospital In-Patient Enquiry (HIPE) for 1972 (Department of Health and Social Security and Office of
Population Censuses and Surveys, 1974), and tablep 17 of the review (Part 1) for the same year (Offices of Population Censuses and Surveys, 1976a). Each of the broad groups to which the application of SMRs had been proposed by the RAWP was subdivided according to the modification of the $I C D$ 'A' list used in table 9 of the report on HIPE. The estimated average number of beds used daily for each disease category was then compared with the number of deaths attributable to that category. Separate scatter diagrams were constructed for males and females within each broad group, except Chapter IV for which no suitable subdivisions were found to exist. The Figure illustrates one diagram for Chapter $\mathbf{X}$.

\section{Results}

Pearson's correlation coefficient $(r)$ was calculated for each set of data and tests of significance were applied using Student's $t$. The findings are summarised in Table 1.

\section{Discussion}

The significant level of correlation between bed usage and mortality found to exist for the disease categories within Chapters II, VI, VII, VIII, and XIII of the ICD, tends to support the use of SMRs for these five groups as a weighting factor for resource 


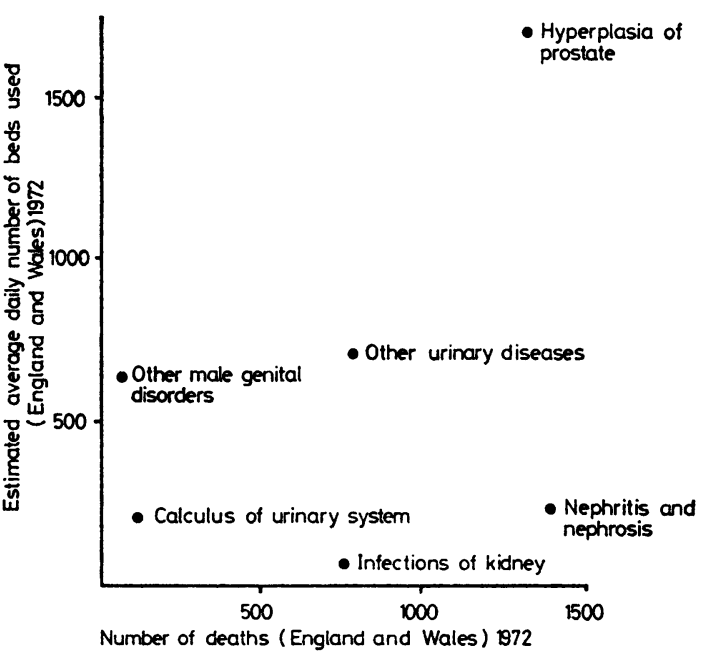

Figure Diseases of the genitourinary system in men.

allocation. The subgroups examined within Chapter III were too few to produce any statistically significant results. The relatively poor correlation for the categories within Chapter X (diseases of the genitourinary system) and Chapter XVII (accidents, poisoning, and violence) poses the question whether SMRs for these groups are an appropriate weighting factor: the findings suggest that diseases which make most demands upon hospital beds may not be those which contribute most to mortality. This does not necessarily invalidate the adoption of these $I C D$ chapter headings in the RAWP's formula, since it is possible that the SMRs for each category within a chapter may follow similar patterns of regional variation. Reference to mortality statistics (Office of Population Censuses and Surveys, 1976a, b) suggests, however, that this is not always so.

The figures for genitourinary disease (Table 2) demonstrate an obvious anomaly in respect of females. Genital conditions accounted for more than $75 \%$ of bed utilisation and contributed less than $5 \%$ of the mortality within this group. There would seem to be a good case for regarding urinary and genital disease in women as distinct entities and weighting regional populations by separate national bed usage rates and separate regional SMRs within the overall RAWP's formula. The same approach might also be adopted for men, in whom genital conditions accounted for two-thirds of the bed usage but less than one-third of the deaths.

Table 1 Correlation between bed usage and mortality for disease categories within 10 ICD Chapters (England and Wales 1972)

\begin{tabular}{|c|c|c|c|}
\hline \multirow{2}{*}{ ICD chapter headings } & \multirow{2}{*}{$\begin{array}{l}\text { No. of } \\
\text { disease categories }\end{array}$} & \multicolumn{2}{|c|}{ Correlation coefficient $(r)$} \\
\hline & & Males & Females \\
\hline $\begin{array}{l}\text { I Infective and parasitic diseases } \\
\text { II Neoplasms }\end{array}$ & $\begin{array}{l}4 \\
10 \text { male } \\
13 \text { female }\end{array}$ & $\begin{array}{l}0 \cdot 98 * \\
0 \cdot 80^{*} *\end{array}$ & $\begin{array}{l}0 \cdot 74 \\
0 \cdot 86^{* *}\end{array}$ \\
\hline $\begin{array}{l}\text { 1II Endocrine, nutritional, and metabolic diseases } \\
\text { VI Diseases of nervous system and sense organs } \\
\text { VII Diseases of the circulatory system } \\
\text { VIII Diseases of respiratory system } \\
\text { IX Diseases of the digestive system } \\
\text { X Diseases of the genitourinary system }\end{array}$ & $\begin{array}{r}3 \\
6 \\
11 \\
6 \\
7 \\
7 \text { male } \\
8 \text { female }\end{array}$ & $\begin{array}{l}0.991 \\
0.90^{*} \\
0.68^{*} \\
0 \cdot 83^{*} \\
0.65 \\
0.42\end{array}$ & $\begin{array}{l}0.995 \\
0.92 * * \\
0.77 * * \\
0.83 * \\
0.79 * \\
\text { Negative value }\end{array}$ \\
\hline $\begin{array}{l}\text { XIII Diseases of the musculoskeletal system and connective tissue } \\
\text { XVII Accidents, poisoning, and violence }\end{array}$ & $\begin{array}{l}7^{7} \text { remale } \\
12\end{array}$ & $\begin{array}{l}0.93 * * \\
0.20\end{array}$ & $\begin{array}{l}0.85^{* *} \\
0.41\end{array}$ \\
\hline
\end{tabular}

*Significant at level $P<0.05$

*Significant at level $P<0.05$
$* *$ Significant at level $P<0.01$

Table 2 Bed usage and mortality for disease categories within ICD Chapter X (England and Wales 1972)

\begin{tabular}{|c|c|c|c|c|}
\hline \multirow[b]{2}{*}{ Disease category } & \multicolumn{2}{|l|}{ Males } & \multicolumn{2}{|l|}{ Females } \\
\hline & $\begin{array}{l}\text { Estimated average } \\
\text { no. of beds used daily }\end{array}$ & No. of deaths & $\begin{array}{l}\text { Estimated average } \\
\text { no. of beds used daily }\end{array}$ & No. of deaths \\
\hline All causes in chapter $\mathbf{X}$ & 3481 & 4356 & 5796 & 3693 \\
\hline
\end{tabular}


Table 3 Bed usage and mortality for disease categories within ICD Chapter XVII (England and Wales 1972)

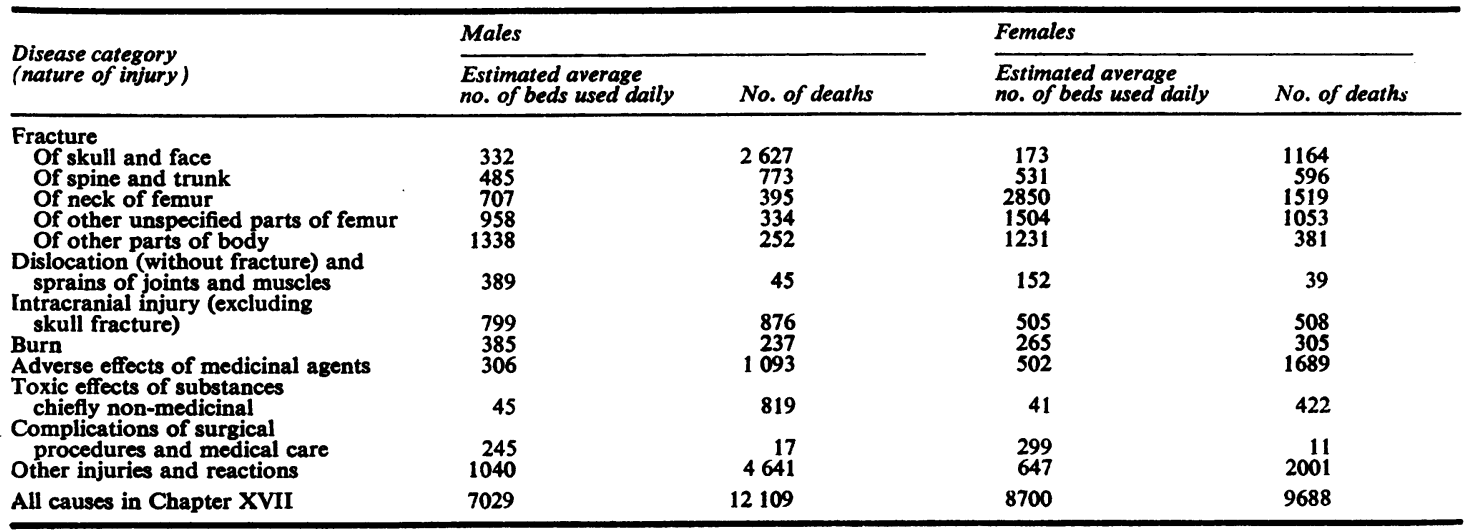

The figures for accidents, poisoning, and violence (Table 3) suggest that if SMRs for this group are to be used in the RAWP's formula, they too should be calculated for separate subdivisions of the chapter. A simpler alternative would be to omit completely the SMR for Chapter XVII from the formula.

Reprints from Roger West, Specialist in Community Medicine, Norfolk Area Health Authority, 102 Prince of Wales Road, Norwich NR1 1LS.

\section{References}

Barr, A., and Logan, R. F. L. (1977). Policy alternatives for resource allocation. Lancet, 1, 994-996.
Department of Health and Social Security (1976) Sharing Resources for Health in England. Report of the Resource Allocation Working Party. HMSO: London.

Department of Health and Social Security and Office of Population Censuses and Surveys (1974). Report on Hospital In-Patient Enquiry for the Year 1972, part 1. HMSO: London.

Forster, D. P. (1977). Mortality, morbidity, and resource allocation. Lancet, 1, 997-998.

Office of Population Censuses and Surveys (1976a) The Registrar General's Statistical Review of Englant and Wales 1972, part 1. HMSO: London.

Office of Population Censuses and Surveys (1976b)? Mortality Statistics (Area) 1974. HMSO: London.

World Health Organisation (1967). International Classification of Diseases, 8th revision, chapters 1-3, 6-10, 13, and 17. WHO: Geneva. 